\title{
Identification of Morphological Characters and Time of Mitotic Musa Paradisiaca cv. Haji
}

\author{
Rina Kurnianingsih ${ }^{1 *}$, Siti Rosidah², Dinda Sekar Ayu', Eka S Prasedya1 ${ }^{1}$, Sri Puji Astuti ${ }^{1}$ \\ ${ }^{1}$ Program Studi Biologi, Fakultas Matematika dan Ilmu Pengetahuan Alam, Universitas Mataram, \\ Mataram, Indonesia; \\ ${ }^{2}$ Laboratorium Immunobiologi, Fakultas Matematika dan Ilmu Pengetahuan Alam, Universitas \\ Mataram, Mataram, Indonesia;
}

\author{
Article History \\ Received : November $22^{\text {th }}, 2021$ \\ Revised : December 09 ${ }^{\text {th }}, 2021$ \\ Accepted : December $18^{\text {th }}, 2021$ \\ Published : December $24^{\text {th }}, 2021$ \\ *Corresponding Author: \\ Rina Kurnianingsih, \\ Program Studi Biologi, \\ Fakultas Matematika dan \\ Ilmu Pengetahuan Alam, Universitas \\ Mataram, \\ Mataram, Indonesia; \\ Email: rkurnianingish@unram.ac.id
}

\begin{abstract}
Musa paradisiaca cv Haji is a local banana of Lombok that has a longer shelf life. The determination of the haji banana genome still uses a scoring method based on morphological character. Clarification of ploidy levels and genome types can be done using chromosome analysis. The initial information needed to perform the karyotype analysis is identifying the cleavage time of $M$. paradisiaca cv Haji. Banana Haji on the island of Lombok has a different local name, so morphological identification of the haji banana accession is required. Morphological observations were conducted on three accessions of Haji bananas from different cultivation sites. Identification of the time of mitosis cleavage is made by the Squash method. The results showed a uniform synapomorphic character in the haji banana accession. The characters include the aspects of pseudostem (normal), shiny pseudostem, imbricate young bractea (young bractea slightly stacked), red inner bractea, straight ovary, and no pigmentation on the stylus. The autapomorphic character of Haji banana accession in this study included inside the pseudostem of the red-green, the position of horizontal fruit bunches, a fair amount of wax on the surface of the lower leaf, and the petiole of the lower leaf in pink. There are morphological character differences in Haji cultivar accession on pseudostem color and tepal color pigmentation. The time of mitosis division in Haji bananas, especially the prophase stage - metaphase from 06.38 - 07.38 Wita. The results obtained in this study can be used as a foundation to conduct karyotype analysis of Musa paradisisaca cv Haji.
\end{abstract}

Keywords: Morphological, mitotic, Musa paradisiaca cv. Haji

\section{Pendahuluan}

Pisang merupakan salah satu komoditas buah unggulan di Indonesia. Luas panen pisang di Indonesia mengalami peningkatan dalam kurun waktu 2013-2019. Pada tahun 2015, luas panen pisang di Indonesia mencapai 94,01 Ha, kemudian tahun 2019 meningkat menjadi 105,8 $\mathrm{Ha}$, namun produktivitas pisang mengalami penurunan dalam kurun waktu tersebut. Pada tahun 2015, produktivitas sebesar 82,27 ton/Ha, tahun 2019 menjadi 68.82 ton/Ha (Badan Pusat Statistik, 2020). Penyebab menurunnya produktivitas ini diantaranya adalah pola tanam yang belum jelas dan teratur, penerapan teknologi budidaya pisang yang benar masih kurang, beragamnya kultivar pisang, penyebaran hama penyakit, ketersediaan dan penggunaan bibit pisang yang sehat dan kultivar unggul masih terbatas (Suhartanto et al., 2012; Hindersah dan Suminar, 2019).

Pengembangan kultivar unggul menjadi salah satu upaya untuk peningkatan produksi pisang, khususnya dari tanaman pisang lokal yang ada di masing-masing daerah. Pada dasarnya pisang lokal memiliki sifat unggul yang diturunkan, misalnya ketahanan terhadap iklim, serta rasa yang khas dan daya simpan yang lama. Pisang lokal dapat menjadi sumber keragaman genetik untuk perbaikan varietas tanaman pisang. Nusa Tenggara Barat khususnya di Pulau Lombok, terdapat beragam jenis pisang lokal dengan karakteristik dan keunggulan masingmasing (Kurnianingsih et al., 2018). Menurut 
Rahayu dan Fitrahtunnisa (2014), Balai Pengkajian Teknologi Pertanian (BPTP) NTB mengoleksi 15 jenis pisang lokal di kebun koleksi sumber daya genetik. Salah satu pisang lokal yang terdapat di NTB adalah pisang haji atau disebut dengan pisang Sambelia atau pisang Bile Mandar.

Pisang Haji memiliki daya simpan yang lebih lama dibandingkan jenis pisang lainnya atau produk hortikultura pada umumnya. Daya simpan dapat mencapai 20 hari pada suhu kamar dengan kondisi daging buah masih baik (tidak berair) meskipun kulit buah mulai menghitam dan mengkerut. Waktu simpan yang lama ini menjadi salah satu potensi yang dimiliki oleh pisang Haji. Warna daging buah pisang haji memiliki warna lebih orange dibanding pisang kepok, yang warnanya putih kekuningan. Hal ini mengindikasikan bahwa pisang haji memiliki kandungan senyawa karoten yang tinggi (Fitrahtunnisa, 2017; Istianto, 2015).

Musa paradisiaca cv Haji memiliki nama lokal di Pulau Lombok, diantaranya pisang bile, kelak, sambelia dan sembalun. Rahayu et al., (2015) menyatakan bahwa pisang bile merupakan pisang lokal Lombok. Tim eksplorasi Balai Penelitian Tanaman Buah (Balitbu) Tropika menemukan keberadaan pisang Bile di Flores (Nusa Tenggara Timur), namun populasinya sedikit (Istianto, 2015). Pisang Bile juga terdapat di daerah Buleleng Bali dan memiliki keunggulan daya simpan, cita rasa buah manis kering dan daging buah berwarna kuning oranye (Anonim, 2020). Rai et al., (2018) menyatakan bahwa pisang Bile terdapat di Buleleng Bali, merupakan kelompok cooking banana dan bergenom $\mathrm{AB}$. Jenis genom tersebut berbeda dengan yang dinyatakan oleh Gusmiati et al., (2018). Dwivany et al., 2020 menyatakan pisang Bile termasuk ke dalam kelompok genom ABB. Penentuan genom pisang sampai saat ini masih menggunakan metode skoring berdasarkan karakter morfologi. Analisis pendugaan genom dan ploidi dilakukan berdasarkan skor penentu kelompok genom pisang menggunakan 15 karakter morfologi (Rinaldi et al., 2014), namun pengelompokkan kultivar pisang menggunakan karakter morfologi dianggap kurang akurat karena bersifat subyektif (Probojati et al., 2019). Klarifikasi tingkat ploidi dan jenis genom dapat dilakukan dengan menggunakan analisis kromosom (Simonikova et al., 2020). Penelitian tentang analisis kromosom (kariotipe) dari Musa paradisisca cv Haji belum pernah dilakukan. Informasi awal yang diperlukan untuk melakukan analisis kariotipe adalah identifikasi waktu pembelahan dari M. paradisiaca cv Haji.

Tanaman pisang haji di Pulau Lombok tersebar di beberapa daerah, yaitu Kabupaten Lombok Barat, Kabupaten Lombok Utara (KLU) dan Kabupaten Lombok Timur, namun populasinya sedikit (Fitrahtunnisa, 2017). Tanaman pisang Haji sudah mulai jarang ditemukan sehingga upaya konservasi sangat diperlukan mengingat besarnya potensi yang dimiliki oleh tanaman tersebut. Tahap awal kegiatan konservasi dapat dilakukan dengan melakukan koleksi sampel di Pulau Lombok, namun kendala yang dihadapi adalah penamaan tanaman tersebut masih menggunakan nama daerah, sehingga karakterisasi morfologi aksesi $M$. paradisiaca cv. Haji penting untuk dilakukan. Berdasarkan kondisi tersebut maka dilakukan penelitian dengan tujuan mengidentifikasi karakter morfologi dari aksesi Musa paradisisaca cv Haji dan waktu pembelahan sel mitosis pada ujung akar. Hasil dari penelitian ini dapat digunakan sebagai landasan untuk melakukan analisis kariotipe Musa paradisiaca cv Haji.

\section{Bahan dan Metode}

Penelitian dilakukan pada bulan Juni November 2020. Pengambilan sampel tahap karakterisasi morfologi pisang Haji dilakukan dengan metode purposive sampling. Pengamatan karakter morfologi dilakukan pada 3 aksesi pisang Haji yang terdapat pada lokasi berbeda, yaitu aksesi 1 berasal dari Desa Belanting (Kecamatan Sambelia, Lombok Timur), aksesi 2 berasal dari Desa Sapit (Kecamatan Suela, Lombok Timur), dan aksesi 3 dari Kelurahan Monjok (Mataram). Karakterisasi morfologi mengikuti panduan pada International Plant Genetic Resources Institute (IPGRI)INIBAP/CIRAD (1996) dengan menggunakan organ vegetatif dan generatif. Analisis data morfologi dilakukan secara deskriptif.

Anakan tanaman pisang Haji yang memiliki tinggi $50-100 \mathrm{~cm}$ diperoleh dari lokasi sampling ditanam pada polybag, selanjutnya dilakukan pemeliharaan untuk merangsang pembentukan akar. Pengamatan waktu 
pembelahan mitosis dilakukan di Laboratorium Immunobiologi FMIPA Universitas Mataram. Penentuan waktu pembelahan mitosis dilakukan menggunakan ujung akar tanaman pisang Haji. Pengambilan sampel ujung akar dilakukan pada pukul 06.30 - 10.30 WITA dengan interval waktu 30 menit. Penentuan waktu pengambilan sampel ujung akar dilakukan berdasarkan penelitian yang dilakukan oleh Damayanti (2007) dan Tuapattinaya (2018). Prosedur identifikasi waktu pembelahan mitosis dilakukan menurut Iswantari et.al (2017) dengan modifikasi. Pengambilan akar dilakukan dengan cara pembongkaran disekitar perakaran tanaman sampai akar terlihat, akar dibersihkan dengan air, lalu ujung akar dipotong dengan ukuran 0,5 - 1 $\mathrm{cm}$ menggunakan pinset. Akar yang di ambil di masukkan kedalam larutan fiksatif I (Asam asetat glasial $45 \%$ ), selanjutnya di inkubasi selama 15 menit di dalam freezer, lalu akar dipindahkan ke dalam larutan fiksatif II (Asam asetat glasial $25 \%$ ) dan di inkubasi selama 24 jam di dalam kulkas dengan suhu $\pm 4^{\circ} \mathrm{C}$. Sampel akar dalam larutan fiksatif II di pindahkan ke dalam larutan hidrolisis dan di inkubasi selama 6 menit pada suhu $60^{\circ} \mathrm{C}$ di dalam hot blok. Sampel di pindahkan ke dalam larutan pewarna acetoorcein $2 \%$ di inkubasi pada waterbath dengan suhu $50^{\prime} \mathrm{C}$ selama 20 menit. Ujung akar di letakkan di atas gelas benda yang sudah di sterilkan dengan alkohol $70 \%$, di tetesi dengan gliserin dan tutup dengan kaca penutup. Spesimen di squash dengan jempol sampai selnya terpisah, dapat di geprek juga dengan ujung pensil berpenghapus, selanjutnya pengamatan preparat di bawah mikroskop dengan perbesaran 1000X. Data dalam penelitian ini berupa data kualitatif. Analisis data dilakukan secara deskriptif untuk mengetahui waktu pembelahan mitosis pada ujung akar Musa paradisisca cv. Haji.

\section{Hasil dan Pembahasan}

\section{Identifikasi Karakter Morfologi $M$. paradisiaca cv. Haji}

Hasil identifikasi karakter morfologi pada 3 aksesi pisang Haji menunjukkan bahwa sebagian besar karakter yang terdapat pada ketiga aksesi sama khususnya pada organ vegetatif seragam kecuali pada warna batang semu (Gambar 1) dan pigmentasi pada tepal
(Gambar 2). Hasil karakterisasi morfologi pisang Haji pada penelitian ini sama dengan penelitian Gusmiati et al., (2018) yang melakukan karakterisasi pisang koleksi Kebun Raya Purwodadi LIPI. Salah satu koleksi pisang pada Kebun Raya Purwodadi LIPI adalah pisang Haji.

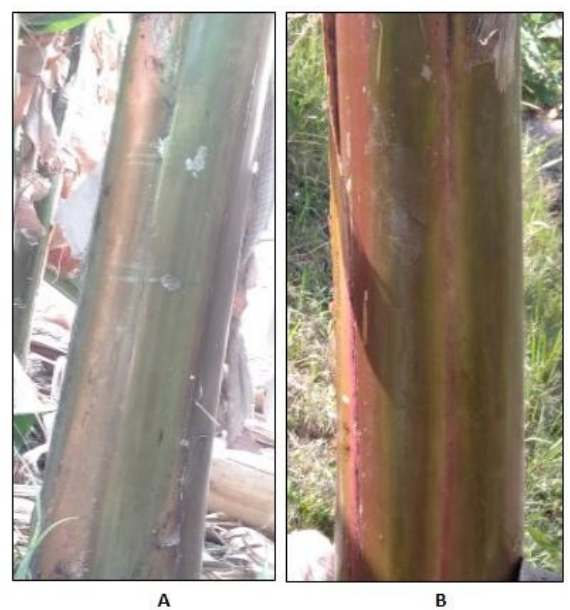

Gambar 1. Warna batang semu; A (aksesi 1) dan (Aksesi 2)

Karakter morfologi organ generatif yang teramati pada ketiga aksesi seragam kecuali karakter pigmentasi pada tepal. Aksesi 1 dan aksesi 3 tidak ada pigmentasi, sedangkan aksesi 2 terdapat pigmentasi pada tepal berwarna merah (Gambar 2).
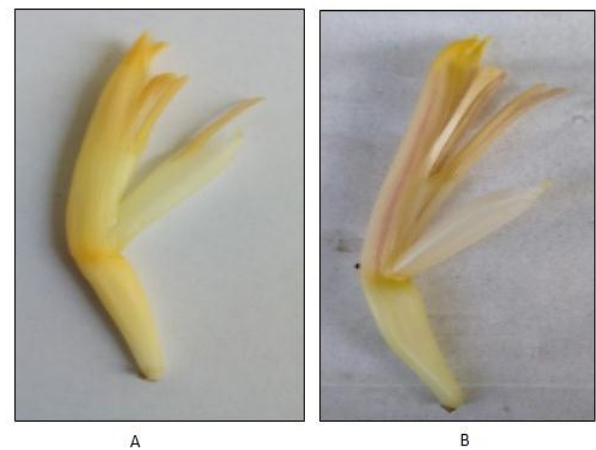

Gambar 2. Pigmentasi pada tepal. A (aksesi 1: tidak ada pigmentasi), B (aksesi 2: pigmentasi berwarna merah)

Musa paradisiaca merupakan hasil persilangan antara tetua Musa acuminata (genom A) dan Musa balbisiana (genom B). Pisang kultivar bergenom ABB memiliki karakter antara kedua tetua tersebut namun lebih banyak mendekati ke tetua $M$. balbisiana 
yang berkontribusi dua genom B. Gusmiati et al., (2018) mengelompokkan pisang Haji ke dalam pisang olahan bergenom ABB berdasarkan beberapa karakter morfologi yng seragam. Karakter ini merupakan karakter sinapomorfi yang merupakan ciri dari kultivar ABB. Karakter tersebut diantaranya pada penampakan tinggi, batang semu, imbrikasi barktea, warna braktea, tidak ada pigmentasi pada stilus dan bentuk ovari. Noor (2020) menyatakan kultivar pisang bergenom ABB memiliki batang semu berkisar 2.1 sampai 2.9 $\mathrm{m}$, dasar batang berwarna dominan hijau, pigmentasi batang berwarna pink keunguan, margin tangkai bersayap dan berwarna hijau. Simpson (2010) menyatakan bahwa, karakter sinapomorfi merupakan karakter yang khas dan diwariskan oleh kelompok takson. Karakteristik sinapomorfi kultivar Haji yang teramati pada penelitian ini sama dengan karakteristik pisang genom ABB pada penelitian Gusmiati et al., (2018) dan Noor (2020). Karakter sinapomorfi tersebut meliputi aspek dari batang semu (normal), batang smeu mengkilat, imbrikasi braktea muda (braktea muda sedikit bertumpukan), braktea bagian dalam berwarna merah, ovari berbentuk lurus dan tidak ada pigmentasi pada stilus.

Gusmiati et al., (2018) menyatakan karakter autopomorfik pisang Haji koleksi Kebun Raya Purwodadi-LIPI diantaranya batang semu bagian dalam berwarna merah, posisi tandan buah yang horizontal, lapisan lilin pada daun bagian bawah dan warna kuningmerah muda pada tulang daun bagian bawah. Karakter autopomorfi merujuk pada sifat-sifat khas yang dimiliki oleh satu spesies atau kelompok. Karakter automorfi aksesi pisang Haji pada penelitian ini meliputi batang semu bagian dalam berwarna merah dengan semburat hijau, posisi tandan buah yang horizontal, lilin yang cukup banyak pada bagian permukaan daun bagian bawah dan tulang daun bagian bawah berwarna merah muda (Gambar 3).
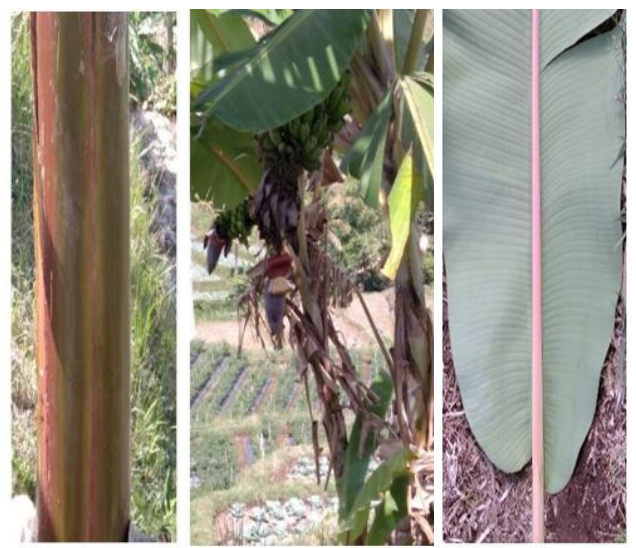

Gambar 3. Karakter autopomorfi Musa paradisiaca $\mathrm{cv}$. Haji

Tabel 1. Hasil Karakterisasi Morfologi Aksesi M. paradisiaca cv. Haji

\begin{tabular}{|c|c|c|c|c|}
\hline No & Karakter Morfologi & Aksesi 1 & Aksesi 2 & Aksesi 3 \\
\hline 1 & $\begin{array}{l}\text { Habitus daun } \\
\text { (Leaf Habit) }\end{array}$ & Tegak & Tegak & Tegak \\
\hline 2 & $\begin{array}{l}\text { Tinggi batang semu (Pseudostem } \\
\text { height) }\end{array}$ & $\geq 3 \mathrm{~m}$ & $2.1-2.9 \mathrm{~m}$ & $2.1-2.9 \mathrm{~m}$ \\
\hline 3 & $\begin{array}{l}\text { Aspek dari batang semu } \\
\text { (Pseudostem aspect) }\end{array}$ & Normal & Normal & Normal \\
\hline 4 & $\begin{array}{l}\text { Warna batang semu (Pseudostem } \\
\text { colour) }\end{array}$ & $\begin{array}{c}\text { Hijau-merah } \\
\text { (dominan hijau) }\end{array}$ & $\begin{array}{l}\text { Hijau-merah } \\
\text { (dominan } \\
\text { merah) }\end{array}$ & $\begin{array}{c}\text { Hijau-merah } \\
\text { (dominan hijau) }\end{array}$ \\
\hline 5 & $\begin{array}{l}\text { Penampakan batang semu } \\
\text { (Pseudostem appearance) }\end{array}$ & $\begin{array}{l}\text { Mengkilat/tidak } \\
\text { berlilin }\end{array}$ & $\begin{array}{c}\text { Mengkilat/tidak } \\
\text { berlilin }\end{array}$ & $\begin{array}{l}\text { Mengkilat/tidak } \\
\text { berlilin }\end{array}$ \\
\hline 6 & $\begin{array}{l}\text { Warna batang semu bagian dalam } \\
\text { (Predominant underlying colour of } \\
\text { the pseudostem) }\end{array}$ & Merah-ungu & Merah-ungu & Merah-ungu \\
\hline 7 & $\begin{array}{l}\text { Pigmentasi batang semu bagian } \\
\text { dalam (Pigmentation of the } \\
\text { underlying pseudostem) }\end{array}$ & Merah & Merah & Merah \\
\hline
\end{tabular}




\begin{tabular}{|c|c|c|c|c|}
\hline 8 & Warna getah (Sap colour) & Seperti susu & Seperti susu & Seperti susu \\
\hline 9 & $\begin{array}{l}\text { Lapisan lilin pada pelepah (Wax on } \\
\text { leaf sheaths) }\end{array}$ & Sangat sedikit lilin & $\begin{array}{l}\text { Sangat sedikit } \\
\text { lilin }\end{array}$ & Sangat sedikit lilin \\
\hline 10 & $\begin{array}{l}\text { Perkembangan sucker (Development } \\
\text { of suckers) }\end{array}$ & $\begin{array}{l}\text { Antara } 1 / 4 \text { dan } 3 / 4 \\
\text { dari tinggi tanaman } \\
\text { induk }\end{array}$ & $\begin{array}{l}\text { Antara } 1 / 4 \text { dan } \\
3 / 4 \text { dari tinggi } \\
\text { tanaman induk }\end{array}$ & $\begin{array}{l}\text { Antara } 1 / 4 \text { dan } 3 / 4 \\
\text { dari tinggi tanaman } \\
\text { induk }\end{array}$ \\
\hline 11 & Posisi sucker (Position of suckers) & $\begin{array}{l}\text { Dekat dengan induk } \\
\text { (pertumbuhan } \\
\text { vertikal) }\end{array}$ & $\begin{array}{l}\text { Dekat dengan } \\
\text { induk } \\
\text { (pertumbuhan } \\
\text { vertikal) }\end{array}$ & $\begin{array}{l}\text { Dekat dengan induk } \\
\text { (pertumbuhan } \\
\text { vertikal) }\end{array}$ \\
\hline 12 & $\begin{array}{l}\text { Bercak pada pangkal tangkai daun } \\
\text { (Blotches at the petiole base) }\end{array}$ & Bercak besar & Bercak besar & Bercak besar \\
\hline 13 & Warna bercak (Blotches colour) & Coklat gelap & Coklat gelap & Coklat gelap \\
\hline 14 & $\begin{array}{l}\text { Kanal tangkai daun (Petiole canal } \\
\text { leaf) }\end{array}$ & Tepi menutup & Tepi menutup & Tepi menutup \\
\hline 15 & Tepi pelepah daun (Petiole margins) & $\begin{array}{l}\text { Bersayap tidak } \\
\text { menjepit batang }\end{array}$ & $\begin{array}{c}\text { Bersayap tidak } \\
\text { menjepit batang }\end{array}$ & $\begin{array}{l}\text { Bersayap tidak } \\
\text { menjepit batang }\end{array}$ \\
\hline 16 & $\begin{array}{l}\text { Warna tepi tangkai daun (Petiole } \\
\text { margin colour) }\end{array}$ & Pink ungu-merah & Pink ungu-merah & Pink ungu-merah \\
\hline 17 & $\begin{array}{l}\text { Warna daun bagian atas (Colour of } \\
\text { leaf upper surface) }\end{array}$ & Hijau sedang & Hijau & Hijau \\
\hline 18 & $\begin{array}{l}\text { Penampakan daun bagian atas } \\
\text { (Appearance of laef upper surfaces) }\end{array}$ & mengkilat & mengkilat & Mengkilat \\
\hline 19 & $\begin{array}{l}\text { Warna daun bagian bawah (Colour } \\
\text { of leaf lower surface) }\end{array}$ & Hijau sedang & Hijau sedang & Hijau sedang \\
\hline 20 & $\begin{array}{l}\text { Penampakan daun bagian bawah } \\
\text { (Appearance of leaf lower surface) }\end{array}$ & Mengkilat & Kusam & Mengkilat \\
\hline 21 & $\begin{array}{l}\text { Lapisan lilin pada daun (Wax on } \\
\text { leaves) }\end{array}$ & Sangat berlilin & Sangat berlilin & Sangat berlilin \\
\hline 22 & $\begin{array}{l}\text { Bentuk dasar daun (Shape of leaf } \\
\text { blade base) }\end{array}$ & Keduanya membulat & $\begin{array}{l}\text { Keduanya } \\
\text { membulat }\end{array}$ & Keduanya membulat \\
\hline 23 & $\begin{array}{l}\text { Warna tulang daun bagian atas } \\
\text { (Colour of midrib dorsal surface) }\end{array}$ & Hijau & Hijau & Hijau \\
\hline 24 & $\begin{array}{l}\text { Warna tulang daun bagian bawah } \\
\text { (Colour of midrib ventral surface) }\end{array}$ & Hijau-merah muda & $\begin{array}{c}\text { Hijau-merah } \\
\text { muda }\end{array}$ & Hijau-merah muda \\
\hline 25 & $\begin{array}{l}\text { Warna bagian atas daun muda yang } \\
\text { masih menggulung/"cigar leaf" } \\
\text { (Colour of cigar leaf dorsal surface) }\end{array}$ & Hijau & Hijau & Hijau \\
\hline 26 & $\begin{array}{l}\text { Warna tangkai tandan buah } \\
\text { (Peduncle colour })\end{array}$ & Hijau & Hijau & Hijau \\
\hline 27 & Posisi tandan buah (Bunch position) & Horizontal & Horizontal & Horizontal \\
\hline 28 & $\begin{array}{l}\text { Penampakan tandan buah (Bunch } \\
\text { appearance) }\end{array}$ & Sangat kompak & Sangat kompak & Sangat kompak \\
\hline 29 & Posisi rakis (Rachis position) & Jatuh vertikal & Jatuh vertikal & Jatuh vertikal \\
\hline 30 & Bentuk jantung (Male bud shape) & Intermediate & Intermediet & Intermediate \\
\hline 31 & $\begin{array}{l}\text { Bentuk dasar braktea (Bract base } \\
\text { shape) }\end{array}$ & Sedang & Sedang & Sedang \\
\hline 32 & $\begin{array}{l}\text { Bentuk ujung braktea (Beact apex } \\
\text { shape) }\end{array}$ & Intermediate & Intermediet & Intermediate \\
\hline 33 & $\begin{array}{l}\text { Imbrikasi braktea (Bract } \\
\text { imbrication) }\end{array}$ & $\begin{array}{l}\text { Braktea muda sedikit } \\
\text { bertumpukan }\end{array}$ & $\begin{array}{l}\text { Braktea muda } \\
\text { sedikit } \\
\text { bertumpukan }\end{array}$ & $\begin{array}{l}\text { Braktea muda sedikit } \\
\text { bertumpukan }\end{array}$ \\
\hline
\end{tabular}




\begin{tabular}{|c|c|c|c|c|}
\hline 34 & $\begin{array}{l}\text { Warna braktea bagian luar (Colour } \\
\text { of the bract external face) }\end{array}$ & Merah-ungu & Merah-ungu & Merah-ungu \\
\hline 35 & $\begin{array}{l}\text { Warna braktea bagian dalam (Colour } \\
\text { of the bract internal face) }\end{array}$ & Merah & Merah & Merah \\
\hline 36 & $\begin{array}{l}\text { Warna ujung braktea (Colour on the } \\
\text { bract apex) }\end{array}$ & $\begin{array}{l}\text { Tidak berwarna } \\
\text { kuning }\end{array}$ & $\begin{array}{l}\text { Tidak berwarna } \\
\text { kuning }\end{array}$ & $\begin{array}{l}\text { Tidak berwarna } \\
\text { kuning }\end{array}$ \\
\hline 37 & $\begin{array}{l}\text { Bekas luka braktea pada rakis } \\
\text { (Bract scars on rachis) }\end{array}$ & Sangat menonjol & Sangat menonjol & Sangat menonjol \\
\hline 38 & $\begin{array}{l}\text { Memudarnya warna pada dasar } \\
\text { braktea (Fading of colour on bract } \\
\text { base) }\end{array}$ & Warna homogen & Warna homogen & Warna homogen \\
\hline 39 & $\begin{array}{l}\text { Bentuk braktea jantan (Male bract } \\
\text { shape) }\end{array}$ & Intermediate & Intermediate & Intermediate \\
\hline 40 & $\begin{array}{l}\text { Pengangkatan braktea jantan (Male } \\
\text { bract lifting) }\end{array}$ & $\begin{array}{l}\text { Terangkat satu per } \\
\text { satu }\end{array}$ & $\begin{array}{l}\text { Terangkat satu } \\
\text { per satu }\end{array}$ & $\begin{array}{l}\text { Terangkat satu per } \\
\text { satu }\end{array}$ \\
\hline 41 & $\begin{array}{l}\text { Pola bukaan braktea sebelum jatuh } \\
\text { (Bract behavior before falling) }\end{array}$ & Menggulung & Menggulung & Menggulung \\
\hline 42 & Lilin pada braktea (Wax on bract) & Sangat berlilin & Sangat berlilin & Sangat berlilin \\
\hline 43 & $\begin{array}{l}\text { Warna compound tepal (Compound } \\
\text { tepal basic colour) }\end{array}$ & Kuning & Kuning & Kuning \\
\hline 44 & $\begin{array}{l}\text { Pigmentasi pada tepal (Compound } \\
\text { tepal pigmentation) }\end{array}$ & $\begin{array}{l}\text { Tidak ada } \\
\text { pigmentasi }\end{array}$ & $\begin{array}{c}\text { Pigmentasi } \\
\text { berwarna merah }\end{array}$ & $\begin{array}{l}\text { Tidak ada } \\
\text { pigmentasi }\end{array}$ \\
\hline 45 & $\begin{array}{l}\text { Warna lobus tepal (Lobe colour of } \\
\text { compound tepal) }\end{array}$ & Kuning & Kuning & Kuning \\
\hline 46 & $\begin{array}{l}\text { Perkembangan tepal bebas (Lobe } \\
\text { development of compound tepal) }\end{array}$ & Berkembang & Berkembang & Berkembang \\
\hline 47 & $\begin{array}{l}\text { Warna tepal bebas (Free tepal } \\
\text { colour) }\end{array}$ & $\begin{array}{l}\text { Semburat berwarna } \\
\text { kuning }\end{array}$ & $\begin{array}{c}\text { Semburat } \\
\text { berwarna kuning }\end{array}$ & $\begin{array}{c}\text { Semburat berwarna } \\
\text { kuning }\end{array}$ \\
\hline 48 & $\begin{array}{l}\text { Bentuk tepal bebas (Free tepal } \\
\text { shape) }\end{array}$ & Oval & Oval & Oval \\
\hline 49 & Warna filamen (Filament colour) & Krem & Krem & Krem \\
\hline 50 & Warna anter (Anther colour) & Krem & Krem & Krem \\
\hline 51 & $\begin{array}{l}\text { Warna kantong polen (Pollen sac } \\
\text { colour) }\end{array}$ & Abu-abu & Abu-abu & Abu-abu \\
\hline 52 & $\begin{array}{l}\text { Warna dasar stilus (Style basic } \\
\text { colour) }\end{array}$ & Putih & Putih & Putih \\
\hline 53 & $\begin{array}{l}\text { Pigmentasi stilus (Pigmentation on } \\
\text { style) }\end{array}$ & Tanpa pigmentasi & Tanpa pigmentasi & Tanpa pigmentasi \\
\hline 54 & Bentuk stilus (Style shape) & Lurus & Lurus & Lurus \\
\hline 55 & Warna stigma (Stigma colour) & Kuning & Kuning & Kuning \\
\hline 56 & Bentuk ovari (Ovary shape) & Lurus & Lurus & Lurus \\
\hline 57 & $\begin{array}{l}\text { Warna dasar ovari (Ovary basic } \\
\text { colour) }\end{array}$ & Krem & Krem & Krem \\
\hline 58 & $\begin{array}{l}\text { Pigmentasi ovari (Ovary } \\
\text { pigmentation) }\end{array}$ & $\begin{array}{l}\text { Sangat sedikit atau } \\
\text { tidak ada pigmentasi }\end{array}$ & $\begin{array}{c}\text { Sangat sedikit } \\
\text { atau tidak ada } \\
\text { pigmentasi }\end{array}$ & $\begin{array}{l}\text { Sangat sedikit atau } \\
\text { tidak ada pigmentasi }\end{array}$ \\
\hline 59 & $\begin{array}{l}\text { Warna dominan bunga jantan } \\
\text { (Dominant colour of male flower) }\end{array}$ & Krem & Krem & Krem \\
\hline
\end{tabular}


Identifikasi karakter pada aksesi pisang Haji dilakukan karena nama lokal kultivar tersebut berbeda-beda sehingga diperlukan data atau informasi yang jelas tentang karakter morfologi dari setiap aksesi. Hasil penelitian menunjukkan bahwa, sebagian besar karakter yang teramati di semua aksesi seragam, kecuali pada karakter warna batang semu \& pigmentasi pada tepal. Perbedaan tersebut diduga karena kondisi lingkungan tumbuh yang berbeda. Menurut Ismail et al., (2015), terdapat variasi karakter morfologi dari aksesi kultivar pisang Ambon. Hal tersebut disebabkan karena pengaruh lingkungan tumbuh yang berbeda. Lingkungan berpengaruh besar terhadap pertumbuhan dan perkembangan tanaman pisang, sedangkan faktor genetik pengaruhnya kecil. Faktor lingkungan yang tidak stabil akan mengakibatkan perubahan morfologi dan fisiologi tanaman (Suryani dan Owbel, 2019). Karakter morfologi tanaman pisang dipengaruh oleh lingkungan, sehingga untuk analisis kekebaratan sebaiknya menggunakan pendekatan secara sitologi dan molekule

\section{Identifikasi Waktu Pembelahan Mitosis $M$. paradisiaca cv. Haji}

Mitosis merupakan pembelahan yang menghasilkan sel baru dengan jumlah kromosom yang sama dengan sel asal. Siklus pembelahan sel tanaman kira-kira 17-32 jam, dari rentang waktu tersebut memerlukan waktu antara 30 menit sampai beberapa jam (Syukur et al., 2015). Tahapan pembelahan mitosis yang teramati pada ujung akar tanaman pisang haji adalah profase, metaphase, anafase dan telophase (Gambar 4).

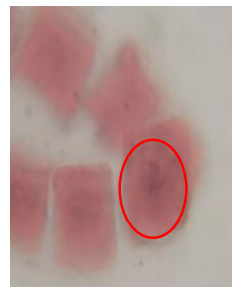

Profase

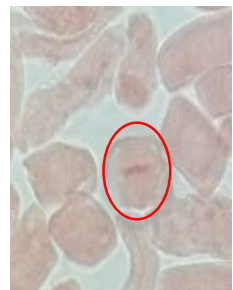

Metafase

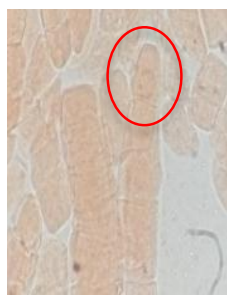

Telofase

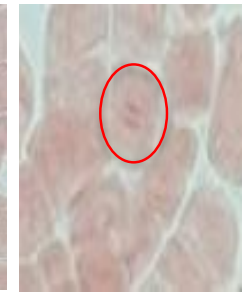

Anafase
Gambar 4. Tahapan mitosis pada ujung akar Musa paradisiaca cv. haji
Pada tahap profase, benang-benang kromatin memadat dan menebal. Kromosom bergerak menuju ke tengah-tengah sel, nukleolus dan membran nukleos menghilang (Pollard et al., 2017; Syukur et al., 2015). Tahap profase pada preparat ujung akar $M$ acuminata $\mathrm{cv}$ Haji terlihat kromosom menyebar dan tebal. Tahap berikutnya adalah metafase, dimana setiap kromosom menjadi kromatid bergerak ke tengah sel (bidang ekuator). Kromosom terlihat lebih pendek dan menebal karena kondensasi kromosom masih berlangsung (Syukur et al., 2015). Pengamatan untuk analisis kariotipe dapat dilakukan pada tahap metafase awal. Pada sediaan kromosom M. acuminata cv Haji, tahap profase - metafase berlangsung mulai pukul 06.38 - 07.38 Wita. Pada tahap anafase, setiap pasangan kromosom memisah dan bergerak ke kutub yang berlawanan. Pada tahap telofase, kromosom mulai mengendur, sel membelah menjadi dua dengan terbentuknya dinding sel yang baru (Syukur et al., 2015). Waktu pembelahan mitosis pada ujung akar bervariasi antara spesies yang satu dengan yang lain. Pembelahan mitosis pada pisang tongkat langit (Musa troglodytarum L.) pukul 09.00 Wit (Tuapattiyana, 2018), tanaman gaharu (Gyrinops versteegii) pukul 06.30-07.00 Wita (Iswantari et al., 2017), markisa ungu (Passiflora edulis) pukul 09.00-15.00 Wita (Muhlisyah et al., 2014), famili Solanaceae pukul 07.00-10.00 Wib (Aristya et al., 2019). Waktu pembelahan optimum pada Allium cepa dan Allium fistulosum pukul $06.00 \mathrm{Wib}$, sedangkan Allium sativum pukul 09.00 Wib (Abidin et al., 2014).

Pembuatan sediaan kromosom menggunakan asam asetat glasial sebagai larutan fiksatif. Proses fiksasi dilakukan dengan tujuan untuk menghentikan proses motabolisme dengan cepat, mengawetkan elemen sitologis dan histologis dan mengawetkan bentuk sebenarnya (Sari et al., 2016). Pewarnaan dilakukan menggunakan aceto orcein. Aceto orcein adalah salah satu pewarna untuk mendapatkan indeks mitosis yang akurat karena mudah untuk membedakan antara inti mitosis dan interfase. Aceto orsein sangat cocok untuk ujung akar karena penetrasinya cepat, serta tahan lama (Mukhlisyah et al., 2014). Pada penelitian ini, pencaran kromosom tidak terlihat jelas, kromosom masih menumpuk. Salah satu bahan kimia yang digunakan untuk meningkatkan 
kualitas preparat kromosom adalah Hydroxiquinolin. Penggunaan Hydroziquinolin pada pembuatan preparat akar menghasilkan kromosom mampu memisah dengan baik, menghasilkan warna yang lebih kontras dan batas-batas antar kromosom lebih jelas (Fauziah, 2015).

\section{Kesimpulan}

Berdasarkan hasil dan pembahasan dapat disimpulkan bahwa karakter sinapomorfi seragam pada aksesi pisang Haji. Karakter tersebut meliputi aspek dari batang semu (normal), batang smeu mengkilat, imbrikasi braktea muda (braktea muda sedikit bertumpukan), braktea bagian dalam berwarna merah, ovari berbentuk lurus dan tidak ada pigmentasi pada stilus. Karakter autopomorfi aksesi pisang Haji pada penelitian ini meliputi batang semu bagian dalam berwarna merahhijau, posisi tandan buah yang horizontal, lilin yang cukup banyak pada bagian permukaan daun bagian bawah dan tulang daun bagian bawah berwarna merah muda. Perbedaan karakter morfologi pada aksesi pisang Haji pada warna batang semu dan pigmentasi warna tepal. Waktu pembelahan mitosis pada pisang Haji, khususnya tahap profase - metaphase mulai pukul 06.38 - 07.38 Wita. Hasil yang diperoleh pada penelitian ini dapat digunakan sebagai landasan untuk melakukan analisis kariotipe Musa paradisisaca cv Haji.

\section{Ucapan terima kasih}

Terima kasih kami sampaikan kepada Universitas Mataram karena mendanai penelitian ini melalui Skim Dosen Pemula yang dibiayai dari Sumber Dana DIPA BLU (PNBP) Universitas Mataram, tahun anggaran 2020 Nomor: 2776/UN18.L1/PP/2020.

\section{Referensi}

Abidin, A.Z. (2014). Studi Indeks Mitosis Bawang Untuk Pembuatan Media Pembelajaran Preparat Mitosis. BioEdu, 3(3): $\quad$ 571-579. https://media.neliti.com/media/publication s/245478-studi-indeks-mitosis-bawanguntuk-pembua-c168c7ac.pdf.
Anonim (2020). Katalog Karakterisai Kultivar Pisang.

https://storymaps.arcgis.com/stories/4885 547c8f63438a908915403e878358.

(Tanggal akses 17 November 2021).

Aristya, G.R., Zuyyina, C., Febriansi, D., Ayuningsih, R., Prasiwi, K.D., Nurwijayanti, T.A., Mujahidah, U., \& Renaldy, B. (2019). Karakterisasi Kromososm Spesies Anggota Familia Solanacea. Biotropic The Jurnal of Tropical Biology, 3(1): 24-38. DOI: https://doi.org/10.29080/biotropic.2019.3. $\underline{1.24-38}$

Badan Pusat Statistik (2020). Produksi Tanaman Buah-buahan 2020. https://www.bps.go.id/indicator/55/62/1/p roduksi-tanaman-buah-buahan.html. Tanggal Akses: 9 Oktober 2020.

Damayanti, F. (2007). Analisis Jumlah Kromosom dan Anatomi Stomata Pada Beberapa Plasma Nutfah Pisang (Musa sp.) Asal Kalimantan Timur. Bioscientiae, 4(2):

53-61.

https://ppip.ulm.ac.id/journals/index.php/ bioscientiae/article/view/163

Dwivany F.M., Ramadhan M.R., Lim C., Sutanto A., Nugrahaprdja H., Wikantika K., Pratama S.N., Meitha K., \& Pratiwi A.S. (2020). Bali Bananas (Musa spp L.,) Genetic Relationship Based on Internal Transcribed Spacer 2 (ITS-2). Pertanika Tropical Agriculture Science, 43(4): 583597. DOI: https://doi.org/10.47836/pjtas.43.4.12

Fauziah, A. (2015). Pengaruh Hidroksiquinolin Pada Pembuatan Preparat Kromosom Akar dan Kalus Bawang Putih (Allium sativum L.). Natural B, 3(1): 65-68. https://naturalb.ub.ac.id/index.php/naturalb/article/downloadSuppFile/279/125

Fitrahtunnisa (2017). Pisang haji Sumberdaya Genetik Tanamn Lokal NTB. 
www.ntb.litbang.pertanian.go.id. Tanggal Akses: 9 Oktober 2020.

Gusmiati, L.H., Hapsari, L., \& Wahyudi, D. (2018). Keberagaman dan Pengelompokan morfologi 10 Pisang Olahan (Musa cv Grup ABB) Koleksi Kebun Raya Purwodadi-LIPI. Floribunda, 5 (8): 299 314.

https://www.researchgate.net/publication/ 324908463_Keberagaman_dan_Pengelom pokan Morfologi 10 Pisang Olahan $\mathrm{Mu}$ sa cv Grup ABB Koleksi Kebun Raya Purwodadi - LIPI

Hindersah, R., \& Suminar, E. (2019). Kendala dan Metode Budidaya Pisang di Beberapa Kebun Petani Jawa Barat. Agrologia, 8 (2): $\quad$ 55-62. DOI: http://dx.doi.org/10.30598/a.v8i2.1010

IPGRI-INIBAP/CIRAD (1996). Descriptor for Banana (Musa paradisiaca L.). Diakses dari https.//www.inibap.org.

Ismail, A., Wicaksana, N., \& Daulati, Z. (2015). Heretabilitas, Variabilitas dan Analisis Genetik pada 15 Genotipe Pisang (Musa paradisiaca) Varietas Ambon Asal Jawa Barat Beradasarkan Karakter Morfologi di Jatinangor. Jurnal Kultivasi, 14(1): 9-16. DOI:

https://doi.org/10.24198/kultivasi.v14i1.1 $\underline{2091}$

Iswantari, W., Mulyaningsih, T., \& Muspiah, A., (2017). Karyomorfologi dan Jumlah Kromosom Empat Grup Gyrinops versteegii (Gilg.) Domke. Di Lombok. Jurnal Ilmu Kehutanan, 11(2017): 205211. https://doi.org/10.22146/jik.28284

Istianto, M. (2015). Pisang Bile, Pisang Khas Asal Nusa Tenggara Barat. https://balitbu.litbang.pertanian.go.id/. Akses tanggal: 9 Oktober 2020.

Kurnianingsih, R., Astuti, S.P., \& Ghazali, M. (2018). Karakterisasi Morfologi Tanaman Pisang di Daerah Lombok. Jurnal Biologi Tropis, 18 (2): 235-240. DOI: http://dx.doi.org/10.29303/jbt.v18i2.790
Muhlisyah, N., Muthiadin, C., Wahidah, B.F., \& Aziz, I.R., (2014). Preparasi Kromosom Fase Mitosis Markisa Ungu (Passiflora edulis) Varietas Edulis Sulawesi Selatan. Biogenesis, 2(1): 48-55.DOI: https://doi.org/10.24252/bio.v2i1.467

Noor, F.N. (2020). Hubungan Kekerabatan Serta Pengelompokkan Kultivar Pisang Berdasarkan Marka Morfologi dan Sekuen Intron trnL. Skrispi, Fakultas Sains dan Teknologi, UIN Maulana Malik Ibrahim, Malang.

Pollard, T.D., Earnshaw, W., Lippincott-Scwartz, J., \& Johnson, G. (2017). Cell Biology. Elsevier. Elsevier Academic Express.

Probojati, R.T. (2018). Diversitas Genetik Pisang Raja (Musa x paradisiaca L.) Di Pulau Jawa Berdasarkan Marka RAPD (Random Amplified Polymorphic DNA). Skripsi, Jurusan Biologi Fakultas Sains dan Teknologi, UIN Maulana Malik Ibrahim, Malang.

Rai I.Y., Dwivany F.M., Sutanto A., Meitha K., Sukewijaya I.M., \& Ustriyana I.N.G., (2018). Biodiversity of Bali Banana (Musaceae) and its Usefulness. Hayati Journal of Biosciences, 25(2): 47-53. DOI: $\underline{10.4308 / \mathrm{hjb} .25 .2 .47}$

Sari, D.P., Fatmawati, U., \& Prabasari, R.M. (2016). Profil Hands On Mata Kuliah Mikroteknik di Prodi pendidikan Biologi FKIP UNS. Proceeding Biology Education Confrance. 13(1): 476-481. https://jurnal.uns.ac.id/prosbi/article/view File/5802/5188

Rahayu, M., \& Fitrahtunnisa (2014). Kebun Koleksi Sumber Daya Genetik di BPTP NTB.

https://ntb.litbang.pertanian.go.id/index.p hp/artikel/920-kebun-koleksisumberdaya-genetik-di-bptp-ntb. (Tanggal Akses: 9 OKtober 2020).

Rahayu, M., Fitrahtunnisa, Suriadi, A., Erawati, B.T.R., \& Herawati, N. (2015). Keragaan Invebtarisasi dan Pengelolaan Sumber 
Daya Genetik di Pulau Lombok Provinsi Nusa Tenggara Barat. Prosiding Seminar Nasional Sumber Daya Genetik Pertanian. Balai Penelitian dan Pengembangan Pertanian Kementerian Pertanian. Jakarta.

Rinaldi, R., Mansyurdin, \& Hermanto, C. (2014). Pendugaan Ploidi dan Kekerabatan Beberapa Aksesi Pisang Hasil Koleksi Balitbu Tropika Solok. Jurnal Sainstek, VI(1): 17-23. DOI: http://dx.doi.org/10.31958/js.v6i1.99

Simonikova, D., Nemeckova, A.N., Cizkova, J., Brown, A., Swennen, R., Dolezel, J., \& Hribova, E. (2020). Chromosome Painting in Cultivated Bananas and Their Wild Relatives (Musa spp.) Reveals Differences in Chromosome Structure. International Journal of Molecular Sciences, 21(7915): $1-17$.

https://doi.org/10.3390/ijms21217915

Simpson, M. G. (2010). Plant Systhematic. Elsevier. Elsevier Academic Express.

Suhartanto, R., Sobir \& Harti, H. (2012). Teknologi Sehat Budidaya Pisang: Dari Benih Sampai Pasca Panen. Pusat Kajian Hortikultura Tropika, Lembaga Penelitian dan Pengabdian Kepada Masyarakat Institut Pertanian Bogor. Bogor.

Suryani, R \& Owbel. (2019). Pentingnya Eksplorasi dan Karakterisasi Tanaman Pisang Sehingga Sumber Daya Genetik Tetap Terjada. Agro Bali (Agricultural Journal), 2(2): 64-76. https://ejournal.unipas.ac.id/index.php/Ag ro/article/view/410/335

Syukur, M., Sastrosumarjo, S., Wahyu, Y., Aisyah, S.I., Sujiprihati, S., \& Yunianti, R. (2015)). Sitogenetika Tanaman. IPB Press. Bogor.

Tuapattinaya, P.M.J. (2018). Analisis Kariotipe Pada Tanaman Pisang Tongkat Langit (Musa troglodytarum L) Serta Sumbangan Ilmiah Bagi Mata Kuliah Anatomi Tumbuhan. Jurnal Biolgy Sciemce \& Education, $\quad 7 \quad$ (1): $\quad 56-63$.
DOI:

http://dx.doi.org/10.33477/bs.v7i1.393 